\section{Response of Lychee Fruit to Cold and Gamma Irradiation Treatments for Quarantine Eradication of Exotic Pests}

\author{
Raymond G. McGuire \\ Agricultural Research Service, U.S. Department of Agriculture, 13601 Old \\ Cutler Road, Miami, FL 33158
}

Additional index words. Litchi chinensis, Anastrepha suspensa, postharvest quality

\begin{abstract}
In separate treatments, fruit of Litchi chinensis Sonn. were subjected to 15 days at $1.1{ }^{\circ} \mathrm{C}$ or to gamma irradiation from a ${ }^{60} \mathrm{Co}$ source at dosages of 100,200 , or $300 \mathrm{~Gy}$. Coldtreated 'Mauritius' fruit lost some color intensity externally and internally, and the pale flesh had a greener hue. The pericarp of 'Brewster' fruit was injured to a greater extent by cold treatment than that of 'Mauritius', and the pulp of treated fruit had lower concentrations of acids and soluble solids. Cold treatment increased decay susceptibility of both cultivars. 'Mauritius' fruit were also more susceptible to decay following irradiation at $300 \mathrm{~Gy}$ and 6 days of storage at $5^{\circ} \mathrm{C}$. Both cultivars lost firmness after this treatment. The pericarp of irradiated 'Mauritius' fruit became more orange, whereas the flesh of both cultivars became greener. Irradiated 'Brewster' fruit were less acidic and contained less soluble solids, but sensory evaluations could not differentiate between irradiated and nontreated fruit regardless of cultivar. Loss of quality was minimal with either cold or irradiation treatment, and both should be acceptable for lychees requiring quarantine treatment for eradication of exotic pests.
\end{abstract}

Each year American consumers are becoming more familiar with lychees as these fruit develop a larger niche in the marketplace. These nonclimacteric fruit, native to China, are the size and color of strawberries, but a thin, red, knobby pericarp must first be removed to reveal the sweet, opalescent flesh beneath. South Florida is the only region within the continental United States where climatic conditions allow trees to survive and bear a sizable crop. More than 500 acres are planted to this crop in South Florida, with a harvest in 1995 of 4.283 million pounds worth $\$ 8.566$ million (Univ. of Florida, 1995). This crop in 1995 was similar in acreage and value per pound to that of kiwifruit in California in 1975 , and appears to have the same potential for growth and consumer acceptability. Immigrant populations, primarily from Asia, currently provide the largest markets for lychees in the United States.

Reports that this fruit may harbor tephritid flies (Swanson and Baranowski, 1972) have led California to propose quarantine rules that would require Florida lychees to be treated to kill Caribbean fruit flies [Anastrepha suspensa (Loew)], which are endemic within the growing areas. Current law authorizes cold treat-

Received for publication 30 Dec. 1996. Accepted for publication 7 Apr. 1997. I thank Everton Bather for his technical assistance throughout these experiments and the Lychee Growers' Association of South Florida for its donation of fruits used in these studies. Mention of a trade name does not constitute a recommendation by the U.S. Dept. of Agriculture. The cost of publishing this paper was defrayed in part by the payment of page charges. Under postal regulations, this paper therefore must be hereby marked advertisement solely to indicate this fact. ment for lychees entering the United States with a specific treatment schedule for fruit held at 32 to $35^{\circ} \mathrm{F}\left(0\right.$ to $\left.1.67^{\circ} \mathrm{C}\right)$ (U.S. Dept. of Agriculture, 1996). For eradication of $A$. suspensa at $34^{\circ} \mathrm{F}\left(1.1^{\circ} \mathrm{C}\right)$, an exposure period of $15 \mathrm{~d}$ is required. Alternatively, the U.S. Food and Drug Administration (FDA) has approved the use of ionizing radiation at $\leq 1000$ Gy for treatment of foodstuffs (Young and Bowen, 1986). The International Consultative Group on Food Irradiation has recommended $150 \mathrm{~Gy}$ as a minimum dosage for treating eggs and larvae of tephritid fruit flies to prevent emergence of normal adults and has adopted $300 \mathrm{~Gy}$ as a generic disinfestation to sterilize any adults present or emerging from treated larvae or pupae (Burditt, 1994).

The objective of this work was to evaluate the quality of lychees cold-treated at $1.1^{\circ} \mathrm{C}$ or treated with gamma irradiation from 100 to $300 \mathrm{~Gy}$.

\section{Materials and Methods}

Cold treatment. Panicles of ripe fruit of the early cultivar Mauritius and of the late cultivar Brewster were harvested each of three consecutive weeks from three farms in Dade County, Fla. Early-, mid-, and late-season fruit were harvested from each farm, which represented an experimental replication. At each harvest date, 45 fruit from each farm were cut from the panicles and randomized. Surface color was recorded from 25 fruit per farm with a Minolta CR-200 chroma meter (Minolta Corp., Ramsey, N.J.) calibrated to a standard white reflective plate and recording in the $\mathrm{L} * \mathrm{C} * \mathrm{~h}^{\circ}$ color system (Lightness, Chroma, and hue angle, respectively); measurements were taken across an area $\approx 50 \mathrm{~mm}^{2}$ with diffuse illumination at a viewing angle of $0^{\circ}$ under CIE (Commission Internationale de l'Eclairage) illuminant $C$ conditions. The 45 fruit were then sorted into three groups of 15 In addition to a nontreated control stored at 5 ${ }^{\circ} \mathrm{C}$ for $3 \mathrm{~d}$, fruit were held 1 ) at $1.1 \pm 0.1^{\circ} \mathrm{C}$ for $15 \mathrm{~d}$, then transferred to $5^{\circ} \mathrm{C}$ for $3 \mathrm{~d}$, or 2 ) at 5 ${ }^{\circ} \mathrm{C}$ for $3 \mathrm{~d}$ of preconditioning prior to the $15-\mathrm{d}$ period at $1.1^{\circ} \mathrm{C}$. Fruit were stored in vented plastic bags within vented cardboard boxes.

Following storage, all fruit were rated for the percentages of surface decay and chilling injury with a 12-point visual acuity scale (Horsfall and Barratt, 1945). Decay was evidenced by the development of brown to black surface lesions, with or without signs of sporulation by the pathogen, and chilling injury as pitting within the pericarp. Firmness of each unpeeled fruit was measured with an Instron model 1011 (Instron Corp., Canton, Mass.) fitted with a compression anvil $12 \mathrm{~mm}$ in diameter; resistance was recorded after a compression of $3 \mathrm{~mm}$ at a crosshead speed of 0.25 $\mathrm{mm} \cdot \mathrm{s}^{-1}$. Color of pericarp and the flesh within was measured from each fruit as noted above. Per treatment, the flesh from five fruit from each farm was macerated by separately forcing each through a sieve with holes $\approx 1 \mathrm{~mm}^{2}(16$ mesh). After first measuring its initial $\mathrm{pH}$ with a Corning combination electrode(Thomas Scientific, Swedesboro, N.J.), $5 \mathrm{~g}$ of pulp was titrated with $0.1 \mathrm{M} \mathrm{NaOH}$ to a pH of 8.1 for calculation of the percentage of total acidity. A portion of pulp was centrifuged at $5000 \mathrm{~g}_{\mathrm{n}}$ for $10 \mathrm{~min}$, and a refractive index (Fisher Abbe refractometer; Fisher Scientific Co., Pittsburgh) was determined from the juice for calculation of the percentage of total soluble solids.

Irradiation treatment. As part of the same harvests noted above, panicles of fruit with leaves attached were obtained from three farms, which represented experimental replications. At each harvest date, before treatment, the color of the pericarp of 25 fruit and of the upper surface of 25 leaves per farm was measured as previously described. Panicle segments from each farm, of two to four fruit with attached leaves, were randomized into four groups (15 fruit per farm per group). One group was left untreated; the others were irradiated with a ${ }^{60} \mathrm{Co}$ source of gamma radiation at a rate of $1.35 \mathrm{~Gy} \cdot \mathrm{s}^{-1}$ to yield dosages of 100 , 200 , or $300 \mathrm{~Gy}$. The Gammacell model 220 irradiator, its calibration, and principle of operation have been described by von Windeguth (1986).

After treatment and $6 \mathrm{~d}$ of storage at $5{ }^{\circ} \mathrm{C}$ in vented plastic bags within vented cardboard boxes, fruit were rated as above for percentages of surface decay and pitting indicative of injury, interior and exterior color, firmness, and juice characteristics. The color of the leaves was also reexamined. In a sensory evaluation, nontreated fruit were compared by 10 co-workers with fruit treated at levels of 100 and $300 \mathrm{~Gy}$; fruit harvested from each farm were separately compared at three stations. Tasters were asked to rate external and internal appearance and flavor by placing a slash in the appropriate location on a $63.5 \mathrm{~mm}$ line. 
Lines were bounded by " 1 " on the left end and " 10 " on the right, where " 1 " represented extremely substandard and " 10 " represented well above the standard.

Data analysis. The two cultivars were analyzed separately for their responses to cold and irradiation treatment. Data from cold treatment evaluations were subjected to an analysis of variance (PROC ANOVA) using the SAS statistical software package (SAS, 1985), with means separation by the Ryan-EinotGabriel-Welsh multiple F test (REGWF). Data from the irradiation test were analyzed with PROC GLM in SAS. The nontreated control was compared with fruit treated at each level of irradiation using Dunnett's one-tailed $t$ test to determine if means of characteristics of individual treatments were significantly greater or less than the control. After each analysis, Horsfall-Barratt rating values were converted to mean percentages for estimation of percent surface area decayed or percent surface area injured. Sensory evaluations of irradiated lychee fruit were measured as distances on the lines from the left ("1").

Cold treatment at $1.1^{\circ} \mathrm{C}$ (without pretreatment at $5{ }^{\circ} \mathrm{C}$ ) and treatment by irradiation at 300 Gy were also compared directly. The two treatments and the controls, incorporating data from both cultivars, were analyzed by PROC ANOVA with means separation by REGWF.

\section{Results}

Cold treatment. Cold-treated 'Mauritius' and 'Brewster' lychees were significantly more susceptible to surface decay [primarily, anthracnose caused by Colletotrichum gloeosporioides (Penz.)Penz. \& Sacc. in Penz.] than were nontreated control fruit (Table 1). Decay severity in storage was greater on 'Brewster' fruit but remained $<12 \%$ of the surface area. Cold treatment of 'Mauritius' fruit did not induce chilling injury, but increased the severity of injury on treated 'Brewster' fruit to $3.6 \%$ of the surface area, significantly greater than that of nontreated fruit. Fruit firmness was not affected by cold treatment of either cultivar.

At harvest, the pericarp of 'Mauritius' fruit was lighter, less intensely colored, and more orange than 'Brewster' fruit; $\mathrm{L} * \mathrm{C} * \mathrm{~h}^{\circ}$ values were 40.0, 32.5, and 35.9, and 37.7, 39.1, and 27.3 , respectively $\left(\mathrm{L}^{*} 100\right.$ is white and 0 is black; $\mathrm{C}^{*} 100$ is most intense and 0 is least intense; and $h^{\circ} 0^{\circ}$ is red-purple, $90^{\circ}$ is yellow, $180^{\circ}$ is bluish green, and $270^{\circ}$ is blue). Although the color of the pericarp of 'Brewster' fruit was not affected by cold treatment, that of 'Mauritius' fruit became darker and less intensely colored, but hue was not changed (Table 1). The translucent flesh beneath the pericarp was extremely pale, as indicated by the low values for $\mathrm{C}^{*}$. Although appearing grayish white, the flesh possessed a yellow to green hue that was discernible mechanically; changes due to cold treatment, although significant in some cases, could not be detected visually.

The $\mathrm{pH}$ of pulp from the fruit flesh was not affected by cold treatment (Table 1). 'Mauritius' fruit had a lower $\mathrm{pH}$ and a greater concentration of acids than did 'Brewster' fruit. The concentration of acids in the pulp of both cultivars declined significantly after cold treatment. The percentage of total solids declined after treatment of 'Brewster' fruit, but remained greater than that of 'Mauritius' fruit.

Pretreatment of fruit for $3 \mathrm{~d}$ at $5{ }^{\circ} \mathrm{C}$ prior to the quarantine treatment at $1.1{ }^{\circ} \mathrm{C}$ generally did not improve posttreatment quality, although some aspects of color were maintained longer (Table 1). Pretreatment allowed decay of 'Brewster' fruit to advance with no significant reduction of chilling injury. Pulp characteristics were not improved by pretreatment at $5{ }^{\circ} \mathrm{C}$.

Irradiation treatment. Gamma irradiation increased susceptibility of 'Mauritius' lychee fruit to anthracnose decay (Table 2). Decay severity was greater on 'Brewster' fruit, but, unlike the case with 'Mauritius' fruit, susceptibility did not increase significantly at dosages as high as $300 \mathrm{~Gy}$. There was no effect of irradiation on chilling injury with either cultivar. Firmness of both cultivars was reduced by irradiation at $300 \mathrm{~Gy}$ but not by lower dosages.

The pericarp of 'Mauritius' fruit became more orange with higher doses of irradiation, but other surface color characteristics of this cultivar, and the external color of 'Brewster' fruit, were not affected (Table 2). Within, the flesh of both cultivars was greener following irradiation, but the color intensity was so low that differences were not discernible visually. The color of leaves at harvest, with $\mathrm{L}^{*} \mathrm{C}^{*} \mathrm{~h}^{\circ}$ values of 40.3, 20.7, and 116.3, and 39.4, 21.1, and 124.4 for 'Mauritius' and 'Brewster', respectively, was not significantly affected by irradiation and subsequent storage.

The $\mathrm{pH}$ and concentrations of acids and soluble solids in the pulp of 'Mauritius' fruit were not affected by irradiation, but the $\mathrm{pH}$ of 'Brewster' pulp increased and the percentage of soluble solids declined with treatment at 300 Gy (Table 2). In sensory evaluations, the subjective appearance and taste of irradiated fruit could not be differentiated from control fruit in either cultivar.

Treatment by irradiation at $300 \mathrm{~Gy}$, followed by $6 \mathrm{~d}$ of storage at $5{ }^{\circ} \mathrm{C}$, and cold treatment at $1.1^{\circ} \mathrm{C}$ for $15 \mathrm{~d}$, followed by $3 \mathrm{~d}$ of $5{ }^{\circ} \mathrm{C}$ storage, were compared statistically to determine which might be less damaging (analysis not shown). There were no significant differences in the responses of the two cultivars to the variables of decay, injury, firmness, and color of the pericarp. Cold treatment and irradiation equally increased $(P=$ $0.006)$ decay susceptibility in each cultivar, whereas injury was slightly greater $(P=0.06)$ following cold treatment and firmness more reduced $(P=0.07)$ after irradiation. Changes in these characteristics were minimal, however, and no significant differences were seen between treatments in their effects on pericarp color. The hue of the flesh of 'Mauritius' lychees became significantly greener with both treatments, and especially so following cold treatment, but the color was so pale that differences were not discernible visually. There were also significant differences between treatments in the total soluble solids of 'Mauritius' lychee juice; compared with cold treatment, the concentration of soluble solids was $5 \%$ greater after irradiation.

\section{Discussion}

Florida lychees tolerate treatment at $1.1^{\circ} \mathrm{C}$ for $15 \mathrm{~d}$ and treatment by gamma irradiation at $300 \mathrm{~Gy}$, which provide quarantine security against translocation of the Caribbean fruit fly. Loss of quality is minimal with either method, and the choice of protocol can be determined solely by market factors.

Lychees grown in Hawaii must also be treated to kill or sterilize a variety of fruit flies endemic there before the fruit can be released to markets in the continental United States. Irradiation was previously shown to be effective at 250 Gy (Akamine and Goo, 1977; Balock et al., 1966). These tests and others in Australia (Mitchell et al., 1992) have demonstrated the tolerance of lychees to low dosages of irradiation. Hawaii now proposes a treatment requiring an absorbed dose of $250 \mathrm{~Gy}$ for

Table 1. Quality of lychees after cold treatment of $15 \mathrm{~d}$ at $1.1 \pm 0.1{ }^{\circ} \mathrm{C}$ with or without preconditioning for $3 \mathrm{~d}$ at $5{ }^{\circ} \mathrm{C}$. Controls were stored at $5^{\circ} \mathrm{C}$ for $3 \mathrm{~d}$.

\begin{tabular}{|c|c|c|c|c|c|c|c|c|c|c|c|c|}
\hline \multirow[b]{3}{*}{ Treatment } & \multicolumn{2}{|c|}{ Surface area } & \multirow{3}{*}{$\begin{array}{c}\text { Firmness } \\
(\mathrm{N})\end{array}$} & \multicolumn{6}{|c|}{ Color } & \multicolumn{3}{|c|}{ Juice } \\
\hline & \multirow{2}{*}{$\begin{array}{c}\text { Decayed } \\
(\%)\end{array}$} & \multirow{2}{*}{$\begin{array}{c}\text { Injured } \\
(\%)\end{array}$} & & \multicolumn{3}{|c|}{ Pericarp } & \multicolumn{3}{|c|}{ Flesh } & \multirow[b]{2}{*}{$\mathrm{pH}$} & \multirow{2}{*}{$\begin{array}{c}\text { Acids } \\
(\%)\end{array}$} & \multirow{2}{*}{$\begin{array}{c}\text { Solids } \\
(\%)\end{array}$} \\
\hline & & & & $\mathrm{L}^{*}$ & $\mathrm{C}^{*}$ & $\mathrm{~h}^{\circ}$ & $\mathrm{L}^{*}$ & $\mathrm{C}^{*}$ & $\mathrm{~h}^{\circ}$ & & & \\
\hline & \multicolumn{12}{|c|}{ 'Mauritius'z } \\
\hline Control & $0.7 \mathrm{~b}$ & $0.0 \mathrm{a}$ & $13.5 \mathrm{a}$ & $41.8 \mathrm{a}$ & $36.4 \mathrm{a}$ & $35.4 \mathrm{a}$ & $51.5 \mathrm{a}$ & $2.6 \mathrm{a}$ & $96.1 \mathrm{c}$ & $4.2 \mathrm{a}$ & $0.36 \mathrm{a}$ & $17.9 \mathrm{a}$ \\
\hline Not preconditioned & $3.6 \mathrm{a}$ & $0.3 \mathrm{a}$ & $13.3 \mathrm{a}$ & $40.2 \mathrm{~b}$ & $33.4 \mathrm{c}$ & $37.1 \mathrm{a}$ & $51.6 \mathrm{a}$ & $1.4 \mathrm{~b}$ & $169.0 \mathrm{a}$ & $4.2 \mathrm{a}$ & $0.32 \mathrm{ab}$ & $17.5 \mathrm{a}$ \\
\hline Preconditioned & \multicolumn{12}{|c|}{ 'Brewster'z } \\
\hline Control & $5.5 \mathrm{c}$ & $0.6 \mathrm{~b}$ & $10.7 \mathrm{a}$ & $37.8 \mathrm{a}$ & $39.4 \mathrm{a}$ & $28.0 \mathrm{a}$ & $53.8 \mathrm{~b}$ & $1.4 \mathrm{a}$ & 202.7 a & $4.5 \mathrm{a}$ & $0.27 \mathrm{a}$ & $19.3 \mathrm{a}$ \\
\hline Not preconditioned & $8.6 \mathrm{~b}$ & $3.6 \mathrm{a}$ & $10.0 \mathrm{a}$ & $37.1 \mathrm{a}$ & $38.6 \mathrm{a}$ & $29.1 \mathrm{a}$ & $54.5 \mathrm{~b}$ & $1.3 \mathrm{a}$ & $188.4 \mathrm{a}$ & $4.6 \mathrm{a}$ & $0.21 \mathrm{~b}$ & $18.9 \mathrm{~b}$ \\
\hline Preconditioned & $11.3 \mathrm{a}$ & $2.7 \mathrm{a}$ & $10.4 \mathrm{a}$ & $37.2 \mathrm{a}$ & $39.6 \mathrm{a}$ & $27.7 \mathrm{a}$ & $55.5 \mathrm{a}$ & $1.5 \mathrm{a}$ & $181.5 \mathrm{a}$ & $4.7 \mathrm{a}$ & $0.20 \mathrm{~b}$ & $19.0 \mathrm{~b}$ \\
\hline
\end{tabular}

${ }^{2}$ Mean separation at $P \leq 0.05$ within columns and cultivars based on analysis of variance and the Ryan-Einot-Gabriel-Welsh multiple F test in SAS. 
Table 2. Quality of lychees after gamma irradiation and $6 \mathrm{~d}$ of storage at $5^{\circ} \mathrm{C}$.

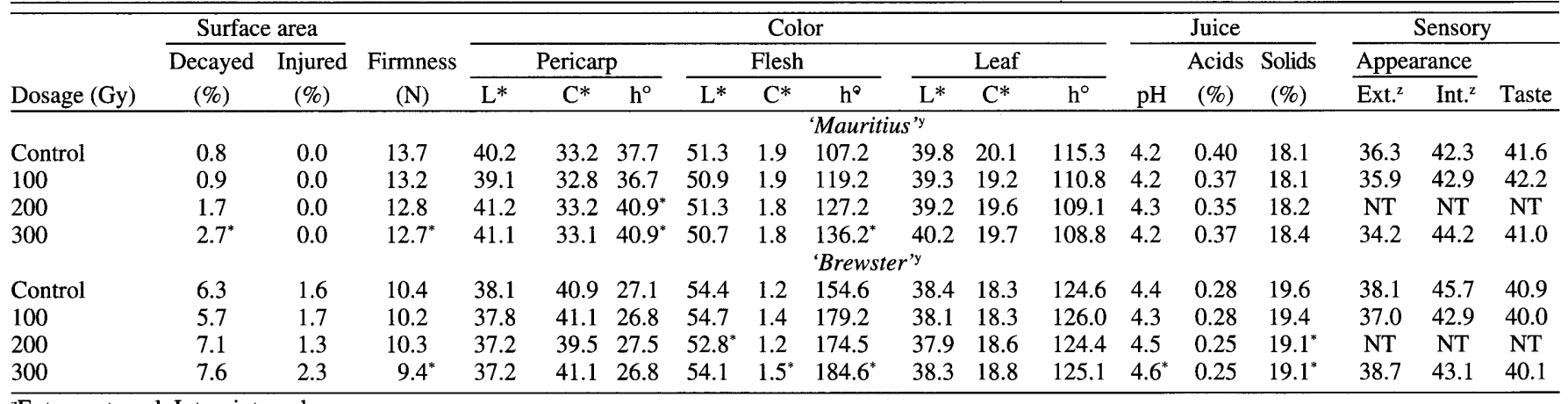

${ }^{\mathrm{z} E x t}$. = external. Int. $=$ internal.

${ }^{y}$ Within columns and cultivars, treatment means followed by $*$ are significantly different from those of control fruit at $P=0.05$ based on analysis of variance and Dunnett's one-tailed $t$ test in SAS. NT = not tested.

lychees destined for markets in the continental United States (Strating, 1996).

Lychees are less tolerant of heat treatments for quarantine control of insect pests. Immersion in water at $60{ }^{\circ} \mathrm{C}$ for 10 min caused the pericarp to brown (Underhill and Critchley, 1993). Vapor heat treatment to a core temperature of $45^{\circ} \mathrm{C}$ for $42 \mathrm{~min}$ was less damaging, as part of an Australian treatment against the Queensland fruit fly (Jacobi et al., 1993). Hawaii has also proposed an alternative heat treatment using immersion in water at $49^{\circ} \mathrm{C}$ for $20 \mathrm{~min}$, followed by hydrocooling (Strating, 1996). Cold treatments for lychees may be more appropriate, however, although they require more time to complete (Paull, 1994), and current APHIS PPQ rules are already in place for such treatment of foreign fruit (U.S. Dept. of Agriculture, 1996). Moreover, cold treatment can be applied during transportation to markets in refrigerated trucks or marine containers that are currently available, whereas heat treatment imposes an additional postharvest step and could require construction of new treatment facilities. Cold temperatures, combined with storage in vented plastic bags that maintain humidity (Campbell, 1994), also better maintain the red color of lychees (Lee and Wicker, 1991). Li et al. (1989) showed that conditioning these fruit by placing them at $5^{\circ} \mathrm{C}$ prior to $1{ }^{\circ} \mathrm{C}$ storage reduced cell membrane permeability and peroxidase activity in the pericarp. Such pretreatment did tend to retain the color of 'Mauritius' fruit, but improvement was slight, and reduction of chilling injury was negligible.

The need to treat Florida lychees prior to export to California may now be moot. Concurrent research demonstrated that these fruit are not a host for the Caribbean fruit fly, whether on the tree or on the ground, or with the pericarp broken to allow the flies entry (Gould et al., 1996). If California accepts these results, quarantine treatment can be avoided for Florida lychees; otherwise, acceptable procedures are available to permit their importation.

\section{Literature Cited}

Akamine, E.K. and T. Goo. 1977. Effects of gamma irradiation on shelf life of fresh lychees (Litchi chinensis Sonn.). Hawaii Agr. Expt. Sta. Res. Bul. 169.

Balock, J.W., A.K. Burditt, S.T. Seo, and E.K. Akamine. 1966. Gamma radiation as a quarantine treatment for Hawaiian fruit flies. J. Econ. Ent. 59:202-204.

Burditt, A.K., Jr. 1994. Irradiation, p. 101-117. In: J.L. Sharp and G.J. Hallman (eds.). Quarantine treatments for pests of food plants. Westview Press, Boulder, Colo.

Campbell, C. 1994. Handling of Florida-grown and imported tropical fruits and vegetables. HortScience 29:975-978.

Gould, W.P., R. Nguyen, M.K. Hennessey, J.L. Sharp, and J. Crane. 1996. Infestation studies on lychees and longans to determine their host status in relation to the Caribbean fruit fly. Proc. Fla. State Hort. Soc. 109:276-277.

Horsfall, J.G. and R.W. Barratt. 1945. An improved grading system for measuring plant disease. Phytopathology 35:655. (Abstr.)

Jacobi, K.K., L.S. Wong, and J.E. Giles. 1993. Lychee (Litchi chinensis Sonn.) fruit quality following vapour heat treatment and cool storage. Postharvest Biol. and Technol. 3: 111-119.
Lee, H.S. and L. Wicker. 1991. Quantitative changes in anthocyanin pigments of lychee fruit during refrigerated storage. Food Chem. 40:263-270.

Li, P., Y.R. Wang, Y.Z. Chen, S. Li, and H.X. Liu. 1989. Effect of cold hardening of litchi fruit on prolonging its cold storage life after harvest. Acta Bot. Austro Sinica 4:143-151.

Mitchell, G.E., R.L. McLauchlan, A.R. Isaacs, D.J. Williams, and S.M. Nottingham. 1992. Effect of low dose irradiation on composition of tropical fruits and vegetables. J. Food Comp. Anal. 5:291311.

Paull, R.E. 1994. Response of tropical horticultural commodities to insect disinfestation treatments. HortScience 29:988-996.

SAS Institute. 1985. SAS user's guide: Statistics. ver. 5. SAS Inst., Cary, N.C.

Strating, A. 1996. Papaya, carambola, and litchi from Hawaii. Fed. Reg. 61:38108-38114.

Swanson, R.W. and R.M. Baranowski. 1972. Host range and infestation by the Caribbean fruit fly, Anastrepha suspensa (Diptera: Tephritidae), in South Florida. Proc. Fla. State Hort. Soc. 85:271274.

Underhill, S.J.R. and C. Critchley. 1993. Lychee pericarp browning caused by heat injury. HortScience 28:721-722.

University of Florida. 1995. Survey data. Florida Agr. Mkt. Res. Ctr., Gainesville.

U.S. Department of Agriculture. 1996. Plant protection and quarantine treatment manual (T107c). U.S. Dept. Agr., U.S. Govt. Printing Office, Washington, D.C.

von Windeguth, D.L. 1986. Gamma irradiation as a quarantine treatment for Caribbean fruit fly infested mangos. Proc. Fla. State Hort. Soc. 99:131-134.

Young, F.E. and O.R. Bowen. 1986. Irradiation in the production, processing, and handling of food; final rule. Fed. Reg. 51:13375-13399. 